\title{
Hate Speech and Democratic Citizenship
}

(C) Eric Heinze (OUP, 2016) (Please do not cite, reproduce or circulate without permission)

The text below comprises Chapter 1 (Introduction) of the monograph Hate Speech and Democratic Citizenship to be published by Oxford University Press in February 2016 (http://tinyurl.com/o8gb8om)

Prof. Eric Heinze

Faculty of Laws

Queen Mary University of London

London E1 4NS

E.Heinze@qmul.ac.uk 


\section{Introduction}

In late September 2005, an ordinary newspaper sparked an extraordinary war. The Danish Jyllands-Posten dropped not a single bomb - except one sketched into the Prophet's turban. As the New Year arrived, disputes around its twelve Muhammad cartoons were still mostly confined to Denmark. But within the month, reprints began to emerge in Norway, France, Italy, Germany, Belgium and the Netherlands. Reports soon rushed in about 'anger flashing through the Muslim world.' 1 Syrians sacked and burned the Danish and Norwegian embassies. Protests in Afghanistan and Somalia claimed several lives. $^{2}$

It was a war about free expression. The Iranian-American scholar Reza Aslan blasted the cartoons as 'fodder for the clash-of-civilizations mentality that pits East against West. ${ }^{3}$ Yet the British columnist Bruce Anderson railed at 'soggy liberals' in the West to 'stop cringing' and 'stand up for our own values'. 4 The French writer Pierre Jourde saw some irony. 'In the West, the most sacred God, the one we dare not touch, is Allah. We

laugh at Jesus and his father as much as we like. ${ }^{5}$ Jourde's compatriot Régis Debray fired back: 'The lack of historical sensitivity among the hard-and-fast libertarians betrays a thoroughly imperial attitude. We may have removed our imperial hats, but our

\footnotetext{
${ }^{1}$ Fisk, 2006. Cf. Bleich, 2011, pp. 3-4.

${ }^{2}$ BBC News, 2006.

${ }^{3}$ Aslan, 2006.

${ }^{4}$ Anderson, 2006.

5 Jourde, 2006.
} 
bearing remains colonial: the world must do as we do, lest it be declared primitive or savage. 6

Predictably pungent were the views of Ayaan Hirsi Ali. Born in 1969 in Mogadishu, Ali had risen, by the age of 33, to the rank of elected representative to the Dutch parliament. She received death threats after writing a screenplay for Theo van Gogh's Submission. The film depicts controversial Koranic verses being projected onto the body of a naked woman. ${ }^{7}$ Ali condemned intellectuals who 'live off of free speech, but then accept censorship. ${ }^{8}$ She chided Western cowardice:

In 1980 the British network ITV showed a documentary about the stoning of a Saudi Arabian princess who had reportedly committed adultery. When the Riyadh government complained, British authorities apologised. We saw the same appeasement in 1987 for a sketch about Ayatollah Khomeini. Then, in 2000, the play Aisha, about the Prophet's youngest wife, was cancelled even before its premiere in Rotterdam. [...] Since van Gogh's murder, writers, journalists and artists shut their mouths. Everyone is afraid to criticize Islam. Submission is still not shown in cinemas. ${ }^{9}$

Meanwhile there are those who would censor insults to their own views, but relish the freedom to offend others. Sir Iqbal Sacranie, then Secretary General of the Muslim Council of Britain, protested that 'Muslims respect and love the Prophet as being

${ }^{6}$ Quoted in Fredet, 2006.

${ }^{7}$ Van Gogh was murdered in Amsterdam in November 2004 by the 26-year-old son of Moroccan immigrants. See Burke, 2014.

${ }^{8}$ Quoted in van Walsum, 2006.

${ }^{9}$ Quoted in Traufetter, 2006. 
dearer to them than their own families. ${ }^{10}$ Scarcely a month later, he publicly declared that gays are 'harmful', 'immoral', and 'spread disease' 11 .

The Italian politician Roberto Calderoli unbuttoned his suit during a televised interview to flaunt a T-shirt picturing a cartoon image of the Prophet. ${ }^{12}$ A week later Pope Benedict XVI warned, 'To promote peace and understanding among peoples and individuals, it is necessary and urgent that religions and religious symbols be respected. ${ }^{, 13}$ Within a few months, the Pontiff would nevertheless proclaim: 'Show me just what Muhammed brought that was new, and there you will find things only evil and inhuman.' Not his own words, but those of a $14^{\text {th }}$ century Byzantine emperor. Benedict later apologised, but not before damage had been done. 'The Pope's aggressive, insolent statement,' proclaimed a Turkish official, 'appears to reflect both the hatred within him towards Islam and a Crusader mentality. He has destroyed peace.' 14

\subsection{Hatred and value pluralism}

Many have challenged the 'sticks and stones' adage that 'words can never hurt me'. Words, they argue, can hurt as much as physical attacks. ${ }^{15}$ Racist, sexist, homophobic, and similar epithets become, in the words of the American critical race theorist Mari Matsuda, 'weapons to ambush, terrorize, wound, humiliate, and degrade'. ${ }^{16}$ The African-

\footnotetext{
${ }^{10}$ Quoted in 'Danish Cartoons Depicting the Prophet Muhammad Abuse Our Freedoms', 2005.

11 'Muslim head says gays "harmful”", 2006.

${ }^{12}$ Cavalli, 2006.

${ }^{13}$ Accattoli, 2006.

${ }^{14}$ Owen \& Erdem, 2006.

${ }^{15}$ See generally, e.g., Delgado \& Stefancic, 1999, pp. 3-26; Delgado \& Stefancic, 2004; Langton, 1993; Matsuda et al., 1993.

${ }^{16}$ Matsuda et al., 1993, p. 1.
} 
American scholar Charles Lawrence reminds us that ' $[t]$ he experience of being called "nigger," "spic," "Jap," or "kike" is like receiving a slap in the face. The injury is instantaneous. 17

Two other leading American proponents of hate speech bans, Richard Delgado and Jean Stefancic, recall that, as far back as the Bible, we can find 'the first known discussions of hate speech' in the Western canon. Judeo-Christian Scripture condemns 'cursing the deaf, rebuking neighbours, or scorning others. ${ }^{18}$ Aristotle reproaches people

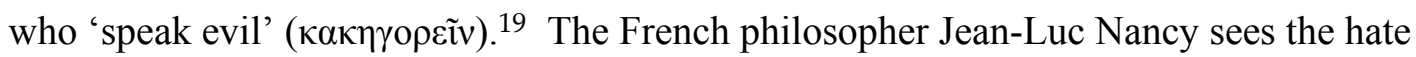
speaker as acting on an 'impulse' that 'can go so far as to seek the destruction of the other. ${ }^{20}$ The German scholar Claudia Hoppe recalls the simultaneously deterrent and symbolic role of hate speech bans as a necessary response to European history. 'Millions of Jews', she recalls, 'were exterminated on grounds of the so-called "race theory".' Hate speech in the Weimar Republic fed fascism, which then overthrew German democracy utterly, leading to history's worst atrocities: 'subsequent generations maintain the responsibility — even if they are not directly guilty — to ensure that such things never happen again. 21

\footnotetext{
${ }^{17}$ Lawrence, 1993, pp 67-68 (emphasis added). Cf. Nancy, 2013, pp 7-8.

${ }^{18}$ Delgado \& Stefancic, 2004, p. 1

${ }^{19}$ Nicomachean Ethics 5.2.1129 ${ }^{\mathrm{b}}$ 23, in Aristotle, [4th century BCE] 1984, vol 2, p 1782 (also translated as 'reviling', 'verbally abusing', or ‘slandering'). Cf. below, text accompanying Section 4.12, note 175.

${ }^{20}$ Nancy, 2013, pp 7-8.

${ }^{21}$ Hoppe, 1998, pp 2 - 3 (emphasis added). Cf Günther, 2000; Grimm, 2009b, p 561; Kailitz, 2004, pp 1112; Pech, 2003, p 160; Suk, 2012; Tsesis, 2002, pp 11-27; Zwagerman, 2009, pp 8-9. Cf. below, text accompanying Section 5.7, notes 196-197.
} 
Today, almost all nations - the United States being a notorious, oft-criticised exception $^{22}$-impose penalties for some form of expression because of its hateful content. Most Western democracies assume what can be called value pluralism. They expect their legislatures and courts to limit the democratic freedoms of some citizens in order to safeguard the interests of other citizens. ${ }^{23}$

Limiting democracy in order to strengthen it is nothing new. Consider our familiar doctrines of separations of powers ${ }^{24}$ and of constitutional checks and balances. They are designed in part, as hate speech bans are designed, with the goal of protecting the vulnerable. No modern democracy, for example, could legitimately hold an election on whether an individual criminal suspect ought to be found guilty. We fear that an innocent suspect could perish under the 'tyranny of the majority' ${ }^{25}$ Of course, courts are as vulnerable to prejudice as are electoral majorities. Still, we want courts, not voters, to render such judgments. We de-democratise that element of democracy in order to protect the very citizens who constitute the democracy.

Modern democracies' regimes of higher-order rights ${ }^{26}$ equally serve as limits on democracy aimed at protecting democracy. An individual right of free expression protects unpopular speakers — political dissidents, social critics—-from popular hostilities.

\footnotetext{
${ }^{22}$ See, e.g., Boyle, 2001; Matsuda, 1993, pp. 26-31; Molnar, 2015; Richards, 1999, pp 2-6, 30-33, 161 80; Stefancic \& Delgado, 1992-93; Waldron, 2012a, pp. 1-6.

${ }^{23}$ On non-citizens, see below, 4.11, text accompanying note 169 .

${ }^{24}$ Cf., e.g., Kelsen, 1920, p. 20.

${ }^{25}$ De la démocratie en Amérique, I:7, in de Tocqueville, [1835] 1999, pp. 348-51; On Liberty, ch. 1, in Mill, [1869] 1991a, p. 8.

${ }^{26}$ Higher-order rights can claim both de jure and de facto existence. Some weaker democracies formally adopt higher-order rights, e.g., in their constitutions, or by statute or treaty, but then largely disregard them. Others, such as Britain, may maintain strong doctrines of parliamentary sovereignty, unbound by higher law, yet can be said to observe higher-order rights de facto on par with other democracies.
} 
For most democracies today ${ }^{27}$, however, the right is curbed against citizens who spread hatred. That limit, too, aims to keep society fair for all citizens. '[A]s a matter of principle', observes the European Court of Human Rights, 'it may be considered necessary in certain democratic societies to sanction or even prevent all forms of expression which spread, incite, promote or justify hatred based on intolerance.' For the Court, 'tolerance and respect for the equal dignity of all human beings constitute the foundations of a democratic, pluralistic society. ${ }^{, 28}$ Sometimes, then, less democracy is 'really' more democracy. According to the British House of Lords member Bhikhu Parekh:

Although free speech is an important value, it is not the only one. Human dignity, equality, freedom to live without harassment and intimidation, social harmony, mutual respect, and protection of one's good name and honour are also central to the good life and deserve to be safeguarded. Because these values conflict, either inherently or in particular contexts, they need to be balanced. $^{29}$

\subsection{Rights, security, and citizenship}

We face a complicated dialectic. With each step, our reasoning strays ever further from democratic foundations. At one remove from democratic processes, the right of free expression protects unpopular speakers by limiting the ability of democratic

\footnotetext{
${ }^{27}$ See generally, e.g., Bleich, 2011; Cohen-Almagor, 2005; Josende, 2010 ; Nieuwenhuis, 2011; Noorloos, 2012; Parekh, 2012; Pech, 2003; Robitaille-Froidure, 2011; Stefancic \& Delgado, 1992-93; Thiel, $2003 \mathrm{a}$.

${ }^{28}$ Gündüz v. Turkey, ECHR, no. 35071/97, judgment of 4 December 2003, para. 40; cf. Erbakan v. Turkey, ECHR, no. 59405/00, judgment of 6 July 2006, para. 56.

${ }^{29}$ Parekh, 2012, p 43 (emphasis added).
} 
legislatures or judges to silence them. The right carves out an exception to the rule of democratic processes in order to safeguard democracy itself. At a second remove, however, hate speech bans place limits upon those limits. That second step equally aims to protect vulnerable citizens, and so to preserve democracy. But then at a third remove, those hate speech bans must face limits of their own. Legislatures and courts must determine how far they extend. They must therefore place limits on the limits on the limits imposed upon democracy.

I shall challenge the view that free expression within public discourse can legitimately be regulated under those prevailing rights regimes. My objection arises not from their complexity as such. Human expression is intrinsically complex. ${ }^{30}$ The wisest legal system could never regulate it through a few simple formulas. Moreover, even several degrees of removal from some core rule-exceptions to exceptions to exceptions - are in themselves nothing unusual in law, as we witness in various tax or commercial codes. And of course individual rights do have a role to play in promoting free expression. ${ }^{31}$

Democratic public discourse, however, demands a stronger protection. It must be safeguarded not only as an individual right, but as an essential attribute of democratic citizenship. It is a perennial mistake to equate the demands imposed upon the state through a regime of rights with the demands imposed upon it as a regime of democracy. Limits must certainly be placed upon democracy in order to preserve it for all citizens. Those limits must themselves be limited, however, when that function encroaches upon the elements that make the state a democracy.

\footnotetext{
${ }^{30}$ See below, Sections 2.5 and 5.3 .

${ }^{31}$ See below, Section 4.4 .
} 
Those two strands of law, the strand of individual rights and the strand of democratic citizenship, certainly overlap. But they are not identical. Much of our talk about democratic citizenship becomes clouded by our talk about individual rights, as if the latter subsume the former. Nor is that the only confusion. We further tend to conflate those two strands with a third, namely, the strand of state security. Hate speech bans may under some circumstances promote the state's security. Protection of vulnerable persons or groups is a standard security concern. ${ }^{32}$ But bans never promote the state's democracy. This book therefore rejects the positions of Delgado \& Stefancic, Lawrence, Matsuda, Nancy, and Parekh. In fact, it rejects the views of almost all legislatures, courts, and international organisations today.

I am by no means the first to challenge hate speech bans. But most writers wage their opposition by claiming the kinds of individual rights or freedoms appearing on our familiar checklists of 'constitutional', 'civil', or 'human' rights and freedoms, including our numerous bills, charters, and treaties of rights. That view tempts us to view problems surrounding expression as self-contained. Self-expression becomes just one of an assortment of rights and freedoms on the list.

Free expression is, of course, no more important to individual or collective welfare than a number of other interests, such as fair trials, protection from torture, or access to food and water. It is, however, the only distinctly democratic interest. A state could easily release its political prisoners or stop torturing without becoming a democracy. It might well provide food and water without becoming a democracy. It might even offer a

\footnotetext{
32 Violence against members of a social group most clearly illustrates the state's concern with hatred as a security interest. The modern state is defined, in part, with reference to its monopoly on defining lawful violence either by state agents (e.g., military or police) or private agents (e.g., self-defence or defence of an innocent third party). Cases in criminal law, for example, are commonly denominated as 'The State versus' the defendant.
} 
considerable margin of free expression without becoming a democracy. It cannot be a democracy, however, without guaranteeing what I shall call the citizen's prerogative of expression within public discourse. Even the right to vote, the more conventional hallmark of democracy, is nothing but an occasional, formalised procedure for exercising that more basic prerogative. Voting is a mere derivative of speaking. ${ }^{33}$

We must distinguish carefully among those three strands of law: the strand of national security, the strand of individual rights, and the strand of democratic citizenship. ${ }^{34}$ They interweave, but one strand can never wholly blend into another without destroying democracy entirely. We fail to regulate expression legitimately until we identify the extent to which expression is not just an important right within democracy, but is materially constitutive of democracy.

No democracy can be seen as constituted solely through one or a series of legal enactments, not even through a comprehensive written 'constitution'. Written democratic constitutions generally confirm the possibility of their own abolition or amendment. And that can only mean: through public discourse. ${ }^{35}$ Through such abolition or amendment clauses, democratic constitutions expressly present themselves as constituted through nothing but an ongoing process of public discourse. That process had established the democracy in the first place, and can at any time re-constitute it. Within a democracy, public discourse is the constitution of the constitution. It is the Urverfassung. That primordial status of viewpoints expressed, however repulsively, within public discourse cannot legitimately lend itself to outright regulation within those democratic legal

\footnotetext{
${ }^{33}$ See below, Section 3.4, text accompanying notes $35-36$.

${ }^{34}$ See below, Section 4.7, text accompanying note 88 .

${ }^{35}$ See below, Chapter 4, text accompanying notes $1-5$.
} 
processes which it constitutes. ${ }^{36}$ Viewpoint-selective penalties imposed upon expression within public discourse can never offer 'less democracy for the sake of more democracy'. They serve only to de-democratise the state, even if they do in some circumstances, like certain other de-democratising measures, serve a security interest.

Contrary to widespread opinion, challenges to speech bans in no way assume a valueneutral state. Such an entity is a conceptual impossibility. Even the most libertarian state would by definition promote libertarian values merely through its actions and omissions. Through word and deed, the modern democracy proclaims its values every day. ${ }^{37}$ Serious opponents of bans do not seek a state callous to inequality. They in no way expect the state to preach that vulnerable groups 'should learn to live with" ${ }^{38}$ hostilities and prejudices. To preserve itself as a democracy, a state must certainly take effective steps to protect the vulnerable and to promote social and civic pluralism. Such measures are indeed legitimately coercive. They include well-established anti-discrimination laws extending to commerce, education, and employment. But it is never 'less democracy for the sake of more democracy' to penalise citizens for expressing within public discourse attitudes even grotesquely hostile to those pluralist values.

My challenge to bans on democratic grounds aims to avoid some common misunderstandings. One would be the assumption that opposition to bans necessarily entails 'marketplace', 'libertarian', 'Americanised', 'neo-liberal', or indeed 'neoconservative' values. Particular points of US free speech law will certainly prove invaluable, in view of the degree of detail with which it has been articulated and refined

\footnotetext{
${ }^{36}$ See below, Section 4.3 , text accompanying note 43 .

${ }^{37}$ See below, Section 4.11 .

${ }^{38}$ Waldron, 2012a, p. 3; Waldron, 2012b, p. 331.
} 
over many years. That does not mean that those doctrines must be incorporated wholesale along with broader political assumptions underlying US legal or political culture. US law provides helpful insights into democracy, not exhaustive ones.

A related misunderstanding concerns the post-World War II model of the European social-welfare state. That model, it has been assumed, justifies bans as means of balancing the supposedly conflicting values of liberty and equality, often portrayed as a standoff between 'American' and 'European' approaches. The democratic model I shall propose will serve to overcome that assumption. It envisages a state that promotes pluralist, antihate worldviews, without having to punish citizens who, within public discourse, crudely spurn that ideal. That model will serve to challenge the widespread view that abolition of bans is, through a kind of historical determinism, suited only to US law and culture. ${ }^{39}$

Pondering democracy's legitimating conditions may smack of an $18^{\text {th }}$ century quaintness. It may seem scarcely suited to the mammoth machines of our post-industrial regulatory, administrative, and surveillance states, often managed by anonymous bureaucracies, corrupted by commercial influence, and tempted to exaggerate state security needs, all the while governing disaffected constituencies. ${ }^{40}$ What delusions can we, in the $21^{\text {st }}$ century, be chasing by seeking yet another holy grail of democratic legitimacy? How much democracy is there left to theorise? Does a focus on democracy pre-suppose, moreover, an outmoded, Enlightenment-era assumption of perfectly rational, autonomous legal subjects? Advocates of bans unsurprisingly depict hate

\footnotetext{
${ }^{39}$ See below, Section 6.1 .

${ }^{40}$ See, e.g., Crouch, 2004; Nancy, 1990; Nancy, 2013, pp. 4-8; Rancière, 2004; Rancière, 2005, p. 29 (discussing Baudrillard), pp. 58-60, 80-81; Rorty, 2004. Cf. Post, 1996-97 (discussing Fiss).
} 
speech as remedies for the decline of equal citizenship, a decline characteristic of atomised and technocratically managed mass societies, which have long drifted from any hope of collective endeavour in the ways Rousseau had once imagined.

Democratic theory must certainly take account of our de-democratised spheres. ${ }^{41} \mathrm{We}$ must distinguish, however, between the descriptive 'is' of observing defects of modern democracies, and the normative 'ought' of deciding which legal rules and social attitudes are best suited to redressing them. Our post-industrial, regulatory and administrative societies present dozens of social and technical problems for which democratic theory as such has little to offer. But the citizen's relationship to public discourse is not one of them. After centuries of political theory, basic relationships among democracy, freedom, rights, and citizenship remain poorly clarified. One of the chances still available to us for tempering the dominion of technocratic and managerial spheres is to seize back into our hands our societies' vestiges of citizen-driven democracy. ${ }^{42}$ Crucial to that aim is insight into democracy's roots in public discourse.

\subsection{Overview}

But what about the dangers of hate speech? One problem for many writers has been to treat them in political abstraction. That reproach may, in two opposed senses, seem odd. From one standpoint, such a reproach seems to underestimate both the problem of hate speech and the passionate reactions to it. Hateful expression, after all, inherently entails political meanings. Protagonists on all sides often take vibrant political stands. From that perspective, it seems strange to suggest that the debate has neglected politics.

\footnotetext{
${ }^{41}$ See below, Section 4.8 , text accompanying note 88 .

${ }^{42}$ See below, Section 4.1, text accompanying note 20 .
} 
From an opposite point of view, my reproach seems to overestimate the character of hate speech - to attribute to it more politics than it deserves. Jeremy Waldron, for example, insists on the materiality of hateful expression. He repeatedly uses metaphors drawn from our responses to the physical world. He speaks in naturalist terms about its 'slow-acting poison', which 'become a disfiguring part of the social environment.' 43 That metaphor's aim is clear. Problems posed by the physical environment, like quicksand or bee stings, take on the veneer of objectivity. They retain their harmful qualities irrespective of the political contexts in which they arise. The harm of a bee sting, and by extension the harm of hate speech, becomes the same in Sweden and in Saudi Arabia. That is why Delgado and Stefancic can, in an essentialist vein, trace the problem of hate speech, which they see in their own world, back to what they view as a sufficiently similar problem within a Biblical community that lived thousands of years ago. From that standpoint, removal of the problem from political contingencies, by bestowing a fixed, material objectivity upon it, seems justified. Advocates of bans often emphasise their quasi-universality. They point to bans embraced across the globe, irrespective of differences among political systems. ${ }^{44}$

I shall agree with the bans' supporters that hateful expression is experienced in painful ways. I disagree, however, that such a harm remains constant in its nature, irrespective of the social and political context in which it arises. Unlike the bee sting, hateful expression is by no means the same thing in Weimar Germany or 1994 Rwanda that it is in early- $21^{\text {st }}$ century Western Europe. Certain solutions may be appropriate for

\footnotetext{
${ }^{43}$ Waldron, 2012a, pp. 4, 30, 31, 33, 37, 39, 45, 59, 65-69, 72, 96-97, 116-17; Waldron, 2012b, p. 331. Cf., critically, Heinze, 2013b, p. 614.

${ }^{44}$ See above, Section 1.1, text accompanying note 22, and below, Section 3.1. But see also below, Section 6.1 , text accompanying notes $40-46$.
} 
some societies, but not for others. That hypothesis will guide this book's journey. I shall certainly examine the harms attributed to hateful expression, but only towards the end, in Chapter 5. I shall considerably postpone, then, what many writers ordinarily assume to be the foremost questions: Is hate speech harmful? If so, what is to be done about it? Unlike the bee sting, we cannot examine the harms attributed to hateful expression 'as such'. We must first examine the political and social contexts in which such expression arises. That is the task of Chapters 2 - 4.

Given what I am claiming to be the constitutive role of public discourse, basic legal and political concepts will enter from the outset. Chapter 2 begins with a review of some familiar, liberal perspectives on free expression. It also briefly surveys the alternative perspectives of republican, communitarian, and critical legal scholars. The discussion then pinpoints certain problems arising around such core concepts as 'freedom', 'liberty', 'liberal', 'speech', 'expression', 'content', 'viewpoint', 'hatred', 'legitimacy', 'public discourse', as well as differences between consequentialist and deontological approaches.

Chapter 3 examines certain failures of our dominant, rights-based systems to recognise the requirements of democracy. Leading liberals like John Rawls or Ronald Dworkin had hailed liberal rights regimes as shields against outright legislative and judicial balancing of conflicting social interests. Rights regimes have, however, themselves become entrenched within those balancing processes. Regimes of individual or human rights may well offer benchmarks for assessing state legitimacy, but in no way provide, nor were they historically conceived to provide, criteria of specifically democratic legitimacy. We must distinguish between the state's legitimacy as a state and 
its legitimacy as a democracy. Whatever anchor free expression may find in rights, we must also recognise its distinct grounding in democratic public discourse. We must distinguish between a liberal or human right of expression and a democratic citizen prerogative of expression.

Supporters of bans often deny that democracies can guarantee any particular safety from the harmful effects of speech. They note that atrocities traceable to hate speech arose in 'on paper' democracies like Germany's Weimar Republic, Rwanda, or the former Yugoslavia. In Chapter 4 it is argued that an historically recent form of democracy has emerged since the 1960s. It can be called the 'longstanding, stable, and prosperous democracy' (LSPD). That model displays internal social and political dynamics which equip LSPDs better than non-LSPDs (non-democracies or weaker democracies) to counter the risks of hate speech. LSPDs offer more politically legitimate and more practically effective ways of preventing the harms of hate speech without having to censor speakers.

The bans' defenders rightly note the historical dangers of hate speech. In Chapter 5, however, it is argued that their empirical claims, made over decades, have never been substantiated for LSPDs. The bans' advocates alternatively postulate notions of indirect or 'symbolic' causation, that 'slow acting poison', whereby hate speech, even if not reliably traceable to harmful material effects, nevertheless acts in subtler yet still deleterious ways. But such views of indirect causation fail to circumscribe a sphere of harmful speech. They render any such delimitation impossible, and any regulation based upon it all the more untenable. In view of those difficulties surrounding both direct and indirect causation of harm within LSPDs, defenders of bans have also taken 'dignitarian', 
positions. They present hate speech as a malum in se, harmful not through further effects, but rather inherently harmful, through its aim to diminish the equal respect and equal citizenship due to all members of society. That claim rests, however, on a category error. A metaphorical denial of citizenship becomes implausibly equated with a literal, material denial of citizenship.

Chapter 6 locates the LSPD model against the broader backdrop of hate speech controversies since the late $20^{\text {th }}$ century. From the very beginnings of global and comparative conversations, a 'US versus the rest of the world' model has emerged. That dualism styles the anti-ban position as aberrantly American, indeed in ways linked to other aberrations of US politics and society. It is a misleading dichotomy, however, both in historical and political terms. It breeds a historical determinism that oversimplifies the broader approaches, and the character of public discourse, not only among democracies, but also between democracies and nondemocracies. The LSPD model offers a more credible lens for distinguishing between those democracies which may, and those which may not legitimately maintain bans. The analysis concludes, in Chapter 7, with a point-by-point review of common arguments favouring bans, and the replies that the LSPD model can offer. 